\title{
Transnistria's public health system and SARS- CoV-2: The challenges of an unrecognized state facing a global pandemic
}

\author{
CRISTIAN VLAS*
}

Independent scholar

Received: February 1, 2021 • Revised manuscript received: April 2, 2021 • Accepted: April 14, 2021

Published online: June 21, 2021

(c) 2021 The Author(s)

\begin{abstract}
The paper presents a comprehensive overview of the public health system in the separatist Trasnistrian region of Moldova, an analytically unorthodox undertaking, as this entails looking at the health system of a fragile breakaway state-like entity, a set of circumstances that - rather inevitably, it seems - may define certain basic features of the health system at hand. Attention will be dedicated to outlining the main challenges the region's public health system faces, for instance, concerning the spread of infectious diseases such as tuberculosis, HIV/AIDS, and SARS-CoV-2. Studying the impact of the coronavirus pandemic can especially serve as a litmus test of the available capacities in Transnistria to deal with public health challenges: facing a novel pathogen, and the related disease and epidemic which threaten to overburden the local institutions. A key question examined here, through the example of Transnistria, is the degree to which international support to the region and the increasing cooperation with the internationally recognized state of Moldova are indispensable for public health security in the unrecognized state.
\end{abstract}

\section{KEYWORDS}

Transnistria, public health, security, unrecognized state, Moldova

\section{JEL CODES}

$\mathrm{H} 77, \mathrm{I18}, \mathrm{P} 48$

\footnotetext{
*Corresponding author. E-mail: cvlas.cv@gmail.com
} 


\section{INTRODUCTION}

In the light of the severe health, economic, and social crises caused by the spread of the SARSCoV-2 virus (WHO 2020), some have arrived at the conclusion that globalization is to blame for the devastating effects of the virus. The usefulness of structures and processes of globalization has been questioned, with fears focusing on how globalisation can serve as a platform and as a mechanism for the spread of viruses. The main claims in this regard are that the virus took "advantage of globalization" (Mas-Coma et al. 2020) and that "globalization has led to the spread of the disease owing to mobility channels such as air and ship travel”, making betterconnected countries more vulnerable to the effects of the pandemic (Shrestha et al. 2020). Moreover, globalization has already been considered as a dominant factor in accelerating disease transmission and increasing "the threat of pandemic emergence" in the past, related to the 2003 SARS epidemic as well as the pandemic waves of influenza, including the most recent H1N1 pandemic of 2009 (Saunders-Hastings - Krewski 2016: 1). While these claims are disputed. The World Health Organization (WHO) attempts to increase and coordinate cooperation and bridge the differences in capacities between its member states, as cooperation in this respect certainly needs to be globalised.

An important question arises exactly related to the criterion of global cooperation: what happens with those populations that live in territories, states, or entities that are not merely unrecognized as states, but, per consequence, not members of the $\mathrm{WHO}$, or, for that matter, of any other international organization? Further questions may also follow: in the absence of data, how can we know the rate of new infections in these territories, and how do conditions within their areas affect regional dynamics of the pandemic? What health systems are there in place in quasi-states? Does the global health system simply ignore the state of these health systems and conditions in these territories, and if so, to what extent, why, and with what implications?

The literature brings little to no insight on the evolution of the public health situation in such territories during 2020, the first full year of the SARS-CoV-2 pandemic. To address this lacuna, this case study of Transnistria's health system aims to assess the questions raised in the previous paragraph, using secondary sources as well as official documents and reports. This case study also brings a new perspective on how the global health system might have significant (territorial) gaps in its coverage of the world, and, consequently, in the fight against the novel coronavirus.

A necessary caveat that needs to be stated in advance is that this article views the Pridnestrovian Moldovan Republic (referred to as Transnistria for the sake of brevity, albeit it is a geographically imprecise name of the area in question), as a subject of scientific research, and not necessarily as a subject of international law or international recognition. Thus, any mention of Transnistria and its institutions ought not to be construed as a political statement concerning recognition of its sovereignty, nor as an attempt to undermine the internationally recognized sovereignty and territorial integrity of the Republic of Moldova.

\section{TRANSNISTRIA AS A BREAKAWAY STATELET}

The internal crises of the Soviet Union and its subsequent dissolution had deviated considerably from the nominal Soviet principle of friendship between nations and ethnicities (mentioned in 
the preamble of the Soviet Constitution) (Istoricheskii Fakultet MGU 2020), leaving behind a legacy of frozen conflicts and de facto states.

One prominent case of a short, but deadly, armed conflict, which remains without a resolution as "frozen", is the Transnistrian conflict (Beacháin 2020). As a result of the 1992 round of fighting between Moldova's constitutional authorities and the self-declared Pridnestrovian Moldovan Republic supported by Russian volunteers and some parts of Russian military units in the region, Transnistria emerged not only as a location for a long-lasting peacekeeping and peacebuilding process, but also as a statehood project, with its capital in Tiraspol, the single important town in the area (King 2001: 531-534; see Figure 1). The relative absence of armed hostilities between the parties have allowed for the secessionist Transnistria to develop its own institutions, such as an army, police, a central bank, and a currency (Caspersen 2012: 83), on the basis of a population made up of around 684,000 people in 1992, reduced to around 467,000 by 2018 (Fomenco 2019: 3).

In the absence of international recognition, Transnitria had become one of the de facto states which "receive popular support and are capable of controlling and providing governance over their territories", as Berg and Toomla put it (2009: 27). Blakkisrud and Kolsto (2011: 204) argue that, in spite of Transnistria being regularly presented as a "racketeer state" due to the alignment of the business and separatist interest groups, it managed to establish state-like structures with a functioning government that can not only secure control of its territory, but also advance its interests and maintain legitimacy. Caspersen (2012: 83) adds to this argument that the statehood-building process in Transnistria was partially "driven by a need for internal legitimacy", that is "closely tied to social justice and fairness", much valued in the post-Soviet space (Protsyk 2006: 39-40). A consolidated state-building process, not entirely successful in stopping emigration (Fomenco 2019), reportedly led Transnistrians to believe that Moldovans are significantly worse off than themselves (Caspersen 2012: 84).

Whether the state-building process was as successful in the health care sector in Transnistria as the above statement may imply, is a question that has not been thoroughly investigated so far.

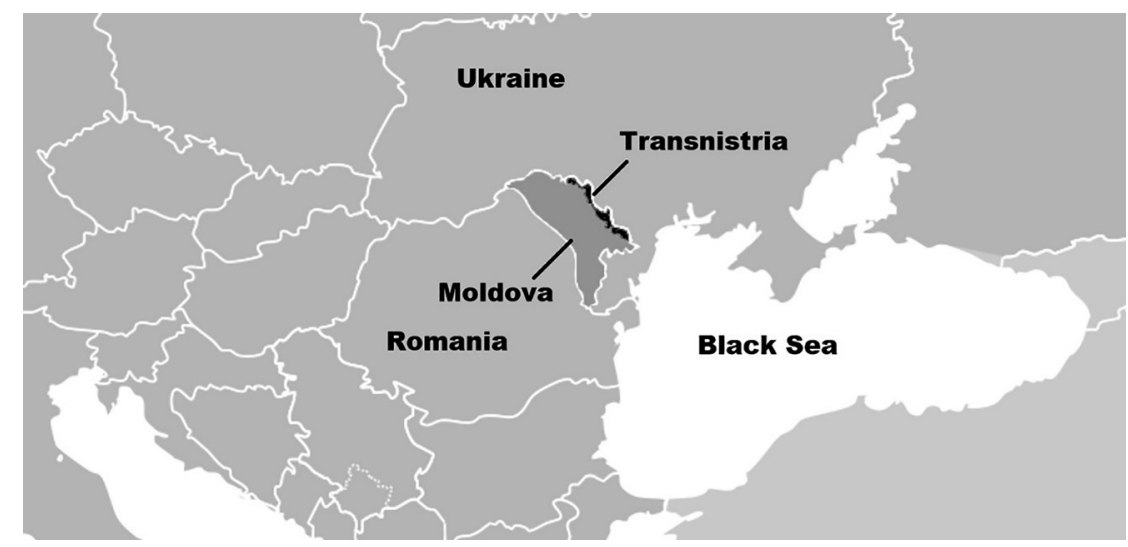

Fig. 1. Regional map showing the location of Moldova and Transnistria 


\section{STATE OF THE HEALTH SYSTEM IN THE QUASI-STATE OF TRANSNISTRIA}

On the notion of the health system, this article will stick to WHO's definition used in the 2008 Tallinn Charter as it is both accurate and broad enough:

Within the political and institutional framework of each country, a health system is the ensemble of all public and private organizations, institutions and resources mandated to improve, maintain or restore health. Health systems encompass both personal and population services, as well as activities to influence the policies and actions of other sectors to address the social, environmental and economic determinants of health (WHO 2008: 1).

The health systems of different states have already been put under review and various categorizations exist. Yet little in the way of academic literature addresses the topic of health systems in quasi-states or unrecognised entities.

The statehood project in Transnistria bears resemblance to the Soviet concept of the state and proof of this is not only the symbolism and language used by Transnistrian officials and institutions in describing the functions of the state, but also the organizational structure and the legislative framework of the state institutions themselves. It would be naive, however, to take for granted that Transnistria is an unchanged remnant republic of the dissolved Soviet Union, with corresponding standards of health care, despite the persistent habit of the Western media to portray it so.

According to Morgoci (2007: 2), the Transnistrian health system largely resembles the features of the 'Semashko' health system, which dates to the establishment of the Soviet healthcare system in the 1920s in the context of wildly spreading communicable diseases and the feeble capacity of the former imperial institutions. The Semashko model primarily translated into a centralized system involving health care units with limited state-funded budgets and health workers with a wide spectrum of expertise, prioritizing "secondary care and inpatient treatment over primary care and outpatient treatment, and focused on curing acute rather than chronic diseases" (Antoun et al. 2011: 437). Morgoci (2007: 2-4) specifies that the structure of the Transnistrian health system can be formulated as consisting of three distinct, yet hierarchical levels:

- central level: the Ministry of Healthcare, ${ }^{1}$ responsible for the overall functioning of the system;

- district level: District departments of health led by district councils, the "Republican Hospital" in Tiraspol, and district clinics;

- local level: every locality is supposed to have either a primary care unit, a unit of obstetric care, or an ambulance unit, involving general practitioners as well as ambulance workers.

Accordingly, the rate of health workers to population is reported to have been stable or even increasing between 2001 and 2006, but primarily because of the general decrease of the region's population (Morgoci 2007). Accordingly, the institution of the general practitioner/family doctor (Gibson et al. 2016: 891-896) is believed to have a rather indistinct role in the whole of the health system (Morgoci 2007: 4). Morgoci points to the training of family doctors by Moldovan universities and the presence of two medical training schools in Transnistria proper. A short inspection of the website of Transnistria's main university (the Pridnestrovian State

\footnotetext{
${ }^{1}$ Министерство здравоохранения Приднестровской Молдавской Республики
} 
University) shows that full medical training in at least five specialties is available, even if it is not internationally widely accredited (PGU 2020).

A 2014 Concept Paper categorizes Transnistria's health system units as consisting of two types: "clinical and urgent" and "stationary" (UL PMR 2014), at the same time underlining the low efficiency of primary health care units, the lack of planning and organization of family medicine, and the heavy reliance on "stationary" units of health care that are, in practice, meant to provide complex medical treatment. Rehabilitation medicine is reported to be absent from the spectrum of local health services, with recovery therapy taking place mostly under the supervision of the family doctor. When talking about medical personnel, the Concept Paper emphasizes that not only is the number of doctors per 10 thousand people (34) lower than in neighbouring Moldova, Ukraine, Russia, or Belarus, but that almost a third of the medical workers are approaching retirement age or are beyond it (UL PMR 2014).

Financially speaking, Transnistria's health system has diverged from the typical Semashko model by transitioning from relying solely on state funds to contributions from paid medical services, from a healthcare fund, as well as from humanitarian medical aid (Morgoci 2007: 4). The region's government also funds specific health programs focused on vaccination, oncology and sexually transmitted diseases (Morgoci 2007: 4). Government sources dating to 2014 acknowledge that the financial needs of the healthcare system were fulfilled only at an average level of $52 \%$ from the state budget, with only $25 \%$ of the necessary medicine stockpiles being bought at the time. The revenues from the provision of non-insured services covered between 5.4 and $8.1 \%$ of healthcare-related needs in the period from 2012 to 2014 (UL PMR 2014). Among the issues with the health system, the 2014 Concept Paper lists the limited financial access to medical services, the lack of a local pharmaceutical industry for the production of medicine for urgent needs, the limited provision of medicine for patients, the lack of appropriate equipment and venues for health care procedures, the lack of high-quality medical services, the devolution of local healthcare/family medicine, the lack of human resources in the sector, the poor organization of the health sector, and the gap between the set prices of medical services and their real market prices (UL PMR 2014).

The legal framework in the health sector is gradually catching up with the international minimum standards, with the country already regularly adopting a medium-term concept on the development of healthcare and adopting regular amendments to healthcare-related legislation (UL PMR 2014; Minzdrav 2020a). While not published yet, the 2020-2026 Concept Paper on the development of health care was reportedly adopted with the help of an expert of the $\mathrm{WHO}$, although it is not clear in terms of the information publically provided by the WHO what the legal connection between the expert in question (Vladimir Shevsky) and the WHO is (Sputnik Moldova 2019; Novosti Pridnestrovya 2019). Referring to the Concept Paper, media sources mention that personnel needs are fulfilled only up to $84 \%$ and $91 \%$, respectively, as regards doctors and medium-skilled health personnel, even as there is an excess of "stationary" doctors as well as hospital beds (Novosti Pridnestrovya 2020a; Novosti Pridnestrovya 2020b). Nevertheless, a $50 \%$ deficit of family doctors is raised as a constant problem, while the present $50 \%$ have to address $70-80 \%$ of the medical needs of Transnistrian patients. Other proposed measures in the 2020 Concept Paper include the centralization of the ambulance service, increasing the number of small, village-based health care units, as well as the better equipment and financial remuneration of medical personnel. 
While these Concept Papers and secondary sources and reports addressing their content bring important insights regarding the state of the Transnistrian health system, the lack of transparency in the publishing of public health data, as well as the general reluctance of the regime to allow researchers and journalists to approach health officials, contribute to a rather poor image of the indicators and conditions that define the region's health system and public health. The preliminary conclusion regarding the region's health system would be that it is significantly underfunded, underequipped, and lacking in human resources. The transition path from the Semashko model seems to be based on the paradoxically simultaneous processes of the further centralization of services and the decentralization of healthcare units. Similar processes took or are taking place across the whole of the post-Soviet space. A quick comparison from as early as 2007 with Moldova's health system reveals, however, the delayed diversification and improvement of revenue sources in Transnistria's health sector, the slow process of adopting family medicine, and the still small role of the Ministry of Healthcare (Morgoci 2007: 7-10). In some ways, the Transnistrian health system has also come to resemble those of post-colonial developing countries or failing states, which "lack developed infrastructure and qualified health personnel" to fulfil the needs of their populations (Homlok 2020: 2-3). Transnistria's reliance on single-disease programs, the "NGOization" of health care (Homlok, 2019: 3), and the dependence on other external actors may be marked as issues for further investigation.

\section{THE IMPACT OF THE UNRECOGNISED STATUS AND EXTERNAL ACTORS ON PUBLIC HEALTH}

It is certain that obstacles in the development of the health system in Transnistria arise at least partly from its unrecognized statehood. The prioritization of military and security expenditures over health spending, the legacy of conflict-related destruction, international trade barriers, a weak economy, the lack of direct ties with the WHO, as well as the tendency of de jure states to block international involvement, would be the first factors that would come into mind when talking about what hinders the work of health systems in de facto states (Vlas 2020a).

Transnistria's case is not as extreme, even though Berg and Toomla have pointed out that the international society tends to boycott the Moldovan separatist region as such (2008: 33). Foreign trade between Transnistria and major-partner economies such as the US, Germany and Romania has been high and has received a boost with Transnistria's participation in the EUMoldova Deep and Comprehensive Free Trade Area (DCFTA; de Waal 2019: 10-12). There are apparently no major barriers to trade as long as the economic agents participating are registered in Chisinau.

Post-conflict material consequences on public health were not investigated in Transnistria, but Caspersen (2012: 34) points out that destruction in Transnistria was "fairly limited" in comparison with the "almost complete" level thereof in Chechnya. A World Bank report points out that the most important economic consequences of the 1992 round of conflict originate from the destruction of two of the four bridges connecting Transnistria to the rest of Moldova, as well as the trade blockades and market measures that followed in the first years from the ceasefire (World Bank 1998: 3-6). The WHO's interest in the separatist region was recently reiterated through an on-demand visit of the WHO mission in Moldova in June 2020 to 
Tiraspol, which found flaws in the entity's treatment protocols, laboratory equipment, medical training, and its health care logistics and acquisitions (TVR Moldova 2020).

Even if health data has not been shared between Chisinau and the separatist administration in Tiraspol since 1997 (Țurcanu et al. 2012: 1; Ciobanu et al. 2018: 68), there are signs that the cooperation between the respective health ministries is operational on an informal level (Morgoci 2007: 11-13), and is currently largely focused on specific projects, such as the surveillance of HIV/AIDS infections, since 2012 (National Coordination Council 2016: 5), or arises on special, extraordinary occasions such as the Covid-19 pandemic. The level of cooperation may seem quite exceptional for a frozen conflict in the post-Soviet space, where the civilians of breakaway regions are often barred from accessing resources from de jure authorities of the regions concerned (Vlas 2020a: 5). One also has to mention that one of the underestimated variables that define public health in the breakaway region and, in fact, in the whole of Moldova, is that some 320,000 Transnistrian residents are Moldovan citizens with Moldovan documents, making them eligible for Chisinau-funded medical care (Guvernul Republicii Moldova 2010). As of October 2020, the Reintegration Ministry reported that 18,000 Transnistrian residents had medical insurance valid in Moldovan healthcare institutions (Deschide.md 2020a). Before the Covid-19 pandemic, the relatively free movement of people (due to extensive family and business ties) to and from the breakaway region may also be an obvious factor that presumably added meaning to more cooperation on public health, at least in the sharing of data from seven Transnistrian centres of "hygiene and epidemiology" (Țurcanu et al. 2012: 86). Additionally, it must be mentioned that the Transnistrian health system relies on the method of outsourcing to Chisinau-based hospitals certain complex treatments such as cardiological surgeries, the implantation/provision of prosthetic devices, and even MRI (magnetic resonance imagery) scans. In the period between July and December 2019 alone, some 436 patients benefited from Tiraspol-funded treatment and medical investigations in Chisinau (Minzdrav 2020d). As the data on complex treatment procedures and investigations is lacking from public records in the breakaway region, one should refrain from saying that its health system relies on Moldova's, but this sort of outsourcing could be an indicator in that regard, and should be definitely investigated further through requests for public information from the Moldovan health authorities and Moldovan hospitals.

As for international involvement, the increasing cooperation with international actors on strengthening or complementing programs through specific projects focused on the health of prisoners, especially in dentistry services (Greadcenco 2016), and the prevention and treatment of communicable diseases. The success of these interventions was the subject of a public debate between journalists, a local ombudsperson and a UN rapporteur. The high rate of HIV/AIDS and tuberculosis infections among prisoners and the inhumane detention conditions and treatment that led to several deaths and applications to the European Court of Human Rights were pointed out (Cucuruz et al. 2016); this pertains not only to those held in Transnistrian prisons, however, but to the entire territory of Moldova (US Department of State 2018; US Department of State 2014: 6-9).

The European Union and the United Nations Development Program both contributed to the public health system in Transnistrian (with Chişinău's knowledge), through projects aimed at confidence-building between the two banks of the Nistru river. A prominent example is the 2017 renovation and expansion of the health care centre in the buffer zone town of Varnița, where up to 13,000 residents of Transnistria can access health care provided by the Moldovan authorities. The expansion of the centre was also based on the data that showed a steady increase in the 
number of Transnistrian residents coming to the centre for health care for at least four consecutive years: from 2013 to 2016 (EU4Moldova 2020). As a kin state, Russia does not contribute, as might be anticipated by some, to the Transnistrian public health system through the granting of free healthcare to the many Russian citizens in the breakaway region, as they do not permanently reside in Russia (Blakkisrud - Kolstø 2011: 192-193). Rather, it does so through humanitarian assistance in the form of providing infrastructure and medical equipment, sometimes in transactions prone to high-level corruption (Tkhorik et al. 2017).

\section{SITUATION DURING THE COVID-19 PANDEMIC: PRELIMINARY FINDINGS}

As of 30 November 2020, the Transnistrian region has registered 12,276 cases of the novel coronavirus, which reportedly led to 245 deaths (Minzdrav 2020b).

The region's health system carries out polymerase chain reaction (PCR) based testing in a state-led laboratory system with branches in 7 towns and cities (Minzdrav 2020c). Upon first glance, the number of daily tests conducted is lower than the WHO-set standard, with the positivity rate hitting even $40 \%$, although the total number of tests conducted since the beginning of the year $(81,044$, to the end of November 2020) might point to a rather lower rate, or alternatively to another point of controversy regarding the accuracy of PCR tests (Novosti Pridnestrovya 2020c; 2020d; 2020g). A stock of 100 thousand coronavirus antibody tests was ordered to decrease reliance on the PCR tests in question (MVD PMR 2020).

Considering the relatively small number of tests conducted in a day and a current stock of only 10 thousand PCR tests, it should not come as a surprise that one of the two of the region's specialized laboratories became dysfunctional in late November 2020, halting operations for a week, being overwhelmed with the volume of work (Novosti Pridnestrovya 2020e). The same lab, founded on the basis of an HIV laboratory but without WHO accreditation, was described by officials in Chisinau as being nearly irrelevant, because it would process only PCR tests and only about 60 tests a day, while the definitive results would still need to be confirmed through labs in Chisinau on the basis of an ad hoc agreement (Basiul 2020; ICG 2020: 9-10). The veracity of the data provided by Transnistria was debated by Chisinau even in September 2020, well into the pandemic, with the authorities hinting at the Tiraspol laboratory's lack of precision in testing and asking for dialogue within the health-focused working group (Braghiş 2020). Additional points of cooperation included the early donation by Chisinau of medicine stocks, the joint efforts to facilitate the return of citizens from abroad (Mihailovici 2020), the possibility to transfer severely ill patients to Moldovan hospitals, and the acceleration of the procedures for importing medical supplies, although with certain reproaches from Tiraspol (ICG 2020: 10).

It is important to point out that Transnistrian officials emulated early on (12 March 2020) the lockdown measures adopted by internationally recognized states such as Moldova, introducing a ban on the entry of non-residents on 17 March, a permit-based system of entry and a quarantine regime for citizens entering the region, and closing down several public institutions. As a conflict point, the quarantine regime also affected around 100 medical workers working in Moldovan institutions (Grâu 2020a), while the deployment of around 37 checkpoints in enclaves controlled by the Moldovan constitutional authorities effectively locked down thousands of people living in the buffer zone who hitherto had largely unimpeded, free movement (Gulca 
2020). This resulted in a relatively large protest in the northern part of the region, with locals demanding free movement (Deschide.md, 2020b). An exception to the quarantine rules was made during the presidential elections of Moldova, when Transnistrian voters were allowed to cross the administrative border, vote, and return to the region without having to undergo a quarantine by showing the "Voted" stamp on their Moldovan identification cards (Balakhnova 2020a). Among the coronavirus measures implemented in the region, one can mention social distancing, the mandatory wearing of face masks and gloves, the switch to digital work and education, a ban on public gatherings, and also a ban on exports of food and agricultural products due to fears over food security (Emerson et al. 2020: 6).

The centralization of the region's regime around the president and the "force structures" (i.e., power institutions including law enforcement) also gave specific features to the management of the health crisis. The main decision-making crisis body was named the "Operational Headquarters", led by the region's interior ministry, but the region's president also issued decrees on restrictions (Emerson et al. 2020: 6). The lack of medical personnel was made up for by drawing on law enforcement personnel and retired military soldiers with medical education, as well as volunteers. The distribution of locally produced surgical masks was initially directed towards the local police, doctors, and the security forces of the separatist region, and masks were only later made available to the general public (Grâu 2020b). Public communication on the health crisis was strongly shaped by the leadership, as print and audiovisual press is controlled by the region's administration (Emerson et al. 2020: 7). Even the public disclosure of the WHO Mission's recommendations to Transnistria by Moldova's Reintegration Minister Cristina Lesnic was formulated by the region's foreign ministry in the media as an interference in internal affairs rather than the voicing of concerns (Novosti Pridnestrovya 2020f). Initially, the visit of the WHO Mission was presented in the local media as an "exchange of expertise" by the region's interior minister and the head of the coronavirus taskforce (Cojocari 2020).

Last, but not least, Russia was one of the first international actors that approached Transnistria with a shipment of 5 thousand PCR tests sent through Chisinau (ICG 2020: 10). In the early stage of the pandemic, France is also reported to have sent testing equipment, while China sent "a variety of medical supplies" (ICG 2020: 10). Local telecom company Interdnestrcom offered some 50 thousand masks, hundreds of pulse oximeters, and 15 disinfection machines (Novosti Pridnestrovya 2020h), while the conglomerate Sheriff donated 10 million local roubles (worth around $\$ 500,000$ as of late November 2020) to the health workers' salary fund (Sheriff 2020), along with Russian oligarch and alleged cryptocurrency investor in the region Igor Chayka (Emerson et al. 2020: 6; Gulca and Necşuțu 2019).

The International Crisis Group (ICG 2020: 11) warns that even with its state-dominated labour market and its electricity, metal and food exports, Transnistria might be vulnerable to a lengthy lockdown, as a 16\% fall in GDP is expected in 2020. Droughts and shrinking remittances from emigrants might worsen the situation, significantly affecting the state budget and thus the health sector. According to the ICG (2020: 9), Transnistria's elderly population would struggle in the fight against the coronavirus, as limited staff and outdated equipment and infrastructure make up a weak health system. Reports from July 2020 mentioned that several coronavirus infections were registered in the trilateral peacekeeping mission (Novosti Pridnestrovya 2020g), an integral part of the conflict resolution efforts, whose current usefulness has been put into doubt (Vlas 2020b). 
Mentioning how the delay of the meetings of the experts' health working group (Guvernul Republicii Moldova, 2020) from both Chisinau and Tiraspol affects coordinated response efforts, the ICG underlines the importance of the political support for regular meetings of the healthfocused working group not only for decreasing tensions, but also saving lives (ICG 2020: 12). The report argues that a better coordinated response to Covid-19 in the conflict zones of the post-Soviet space is sorely needed, emphasizing how building bridges and saving lives can lay the "groundwork for engagement and greater understanding" between warring parties (ICG 2020: 1-2).

The fall of 2020 has seen a rise in the number of new coronavirus cases in the whole of Moldova and Transnistria, with the separatist authorities re-introducing lockdown measures in early October (Gorchak 2020) and even proposing the prolongation of the region's quarantine regime until February 2021 (Balakhnova 2020b). An occupation rate of $83 \%$ in the number of adapted hospital beds suggests a rather high burden on the region's health system (Minzdrav 2020e), although it may seem better than that on Moldova's health system, which reportedly came close to peak capacity due to the extraordinary caseload related to the epidemic (Buzdugan 2020).

A comparison between Transnistria's and Moldova's handling of the coronavirus pandemic would be too early to make in November 2020, but there are certainly lessons for both the separatist authorities of Transnistria and the constitutional authorities of Moldova on how a weak health system functions in a time of crisis.

\section{CONCLUSION}

A lot has been said during the first 10 months of 2020 about the comeback of the state in the present crisis. Paradoxically, some of the governments of post-Soviet Eastern Europe have failed to grasp the benefits from this revamped state role. That includes the case of Moldova, where the consequences of the COVID-19 pandemic, and the resulting economic slowdown, were insufficiently addressed. This pertains not only to the health sector and education, but also to a drop in the rate of employment, and the struggling of small and medium enterprises (Dulgher 2020). Unfortunately, interest in the handling of the COVID-19 pandemic in Transnistria has been steadily decreasing throughout the year, with the government in Chisinau focusing on elections instead.

In the last 28 years, the Transnistrian conflict allowed room for peaceful negotiations on a number of political issues, including on the free movement of people and the work of Romanian language schools in Transnistria. Progress on non-political issues, such as health, was largely ignored by the public. In part due to the lower impact of the conflict on daily life, due to military security priorities, and also due to the relatively equal life quality on both banks of the Nistru river, the Moldovan public and the Moldovan government stand far from acknowledging the importance of cooperation with the Transnistrian separatist regime on humanitarian issues. The separatist regime in Tiraspol is even more reluctant, and has adopted a confrontational discourse regarding Chisinau, hinting at its intentional economic blockade targeting medical supplies and the health system (Agora.md 2020).

Continuous failure to invest enough in the public health system and to provide quality services might erode the legitimacy of the current regime in Tiraspol and, eventually, it might 
force the separatist authorities to rely "on coercion and violence" (Caspersen 2015: 5) instead of social justice and fairness in order to ensure cohesion or even statehood.

While the Moldovan government should perhaps sense an opportunity to work towards reintegration of the country through offering more cooperation to Tiraspol in the handling of the epidemic, the international community, under the coordination of the WHO, ought to ensure that territorial gaps of the kind that breakaway Transnistria constitutes in the global coverage of pandemic response, jeopardizing global efforts to contain the spread of the novel coronavirus, be addressed, including with a view to the need for appropriate vaccination coverage in the region.

\section{REFERENCES}

Agora.md (2020): Cinci informații eronate promovate de autoritățile de la Tiraspol în contextul pandemiei COVID-19 [Five erroneous facts promoted by authorities from Tiraspol in the context of the Covid-19 pandemic]. https://agora.md/stiri/71154/cinci-informatii-eronate-promovate-de-autoritatile-de-latiraspol-in-contextul-pandemiei-covid19, accessed 30/11/2020.

Antoun, J., Phillips, F., Johnson, T. (2011): Post-Soviet Transition: Improving Health Services Delivery and Management. Mount Sinai Journal of Medicine 78: 436-448.

Balakhnova, V. (2020a): Штамп Иили карантин. Как будут голосовать жители Приднестровъя [Stamp or Carantine. How Transnistria Residents Will Vote]. Newsmaker.md. https://newsmaker.md/ rus/novosti/shtamp-ili-karantin-kak-budut-golosovat-zhiteli-pridnestrovya/, accessed 01/11/2020.

Balakhnova, V. (2020b): В Приднестровье могут продлить карантин до 1 февраля 2021 года [Quarantine in Transnistria might be Prolonged Until 1 February 2021]. Newsmaker.md. https:// newsmaker.md/rus/novosti/v-pridnestrove-mogut-prodlit-karantin-do-1-fevralya-2021-goda/, accessed 30/11/2020.

Basiul, V. (2020): Noul laborator de testare de la Tiraspol este considerat neperformant și inutil la Chişinău [The New Testing Laboratory in Tiraspol is Considered Underperforming and Useless in Chisinau]. Radio Europa Liberă Moldova. https://moldova.europalibera.org/a/noul-laborator-de-testare-de-latiraspol-este-considerat-neperformant-\%C8\%99i-inutil-la-chi\%C8\%99in\%C4\%83u-/30572658.html, accessed 14/05/2020.

Blakkisrud, H. - Kolstø, P. (2011): From Secessionist Conflict Toward a Functioning State: Processes of State- and Nation-Building in Transnistria. Post-Soviet Affairs 27(2): 178-210.

Beacháin D. Ó. (2020): Moldova-Transnistria Conflict. In: Richmond O. - Visoka G. (eds): The Palgrave Encyclopedia of Peace and Conflict Studies. Cham: Palgrave Macmillan.

Berg, E. - Toomla, R. (2009): Forms of normalisation in the quest for de facto statehood. The International Spectator 44(4): 27-45.

Braghiş, N. (2020): COVID-19/Vicepremierul pentru Reintegrare: Nu putem să asigurăm că datele care vin de la Tiraspol corespund realității [COVID-19/Vice-prime Minister for Reintegration: We Cannot Ensure that Data Coming from Tiraspol Correspond to the Reality]. Ziarul de Gardă. https://www.zdg. $\mathrm{md} /$ stiri/stiri-sociale/covid-19-vicepremierul-pentru-reintegrare-nu-putem-sa-asiguram-ca-datelecare-vin-de-la-tiraspol-corespund-realitatii/, accessed 30/09/2020.

Buzdugan, L. (2020): Ion Chicu, după şedinţa de lucru cu Igor Dodon şi Zinaida Greceanîi: „Locuri în spitale $n u-s$. Nu mai sunt resurse umane" [Ion Chicu, after the Working Meeting with Igor Dodon and Zinaida 
Greceanii: There no Hospital Beds Left. There are no Human Resources]. TV8. https://tv8.md/2020/11/ 30/video-declaratii-de-presa-dupa-sedinta-de-lucru-a-lui-igor-dodon-cu-zinaida-greceanii-si-ionchicu/, accessed 30/11/2020.

Caspersen, N. (2012): Unrecognized States: The Struggles for Sovereignty in the Modern International System. Cambridge: Polity Press.

Caspersen, N. (2015): Degrees of legitimacy: Ensuring internal and external support in the absence of recognition. Geoforum 66: 184-192.

Ciobanu, A. - Habicht, J. - Serbulenco, A. - Gheorghita, S. (2018): Republic of Moldova. In: Recthel, B. - Maresso, A. - Hernandez-Quevedo, C. - Williams, G. - Richardson, E. - Jakubowski, E. - Nolte, E. (Eds.): Organization and financing of public health services in Europe. London: WHO.

Cojocari, V. (2020): OMS, vizită de lucru în Transnistria. Separatiştii: Vin să învețe de la noi cum să combată pandemia COVID-19 [WHO, working visit in Transnistria. Separatists: They are coming to Learn from us on how to fight the COVID-19 Pandemic]. Deschide.md. https://deschide.md/ro/stiri/ 23/65760/oms-vizit-de-lucru-n-transnistria-separati-tii-vin-s-nve-e-de-la-noi-cum-s-combatpandemia-covid-19.htm, accessed 08/05/2020.

Cucuruz, A. - Brega, G. - Colun, M. (2016): Penitenciarele din regiunea transnistreană - milioane din bugetul public pentru condiții degradante [Penitentiaries from the Transnistrian Region - Millions from the Public Budget for Degrading Condition]. Anticorupție.md. https://anticoruptie.md/ro/investigatii/ social/penitenciarele-din-regiunea-transnistreana-milioane-din-bugetul-public-pentru-conditiidegradante, accessed 29/11/2020.

Deschide.md (2020a): Cristina Lesnic: Pandemia de Covid-19 a scos în evidență noi realități în reglementarea conflictului transnistrean [Cristina Lesnic: COVID-19 pandemic revealed new realities in the Transnistrian conflict settlement]. https://deschide.md/ro/stiri/23/73169/Cristina-Lesnic-Pandemia-deCovid-19-a-scos-\%C3\%AEn-eviden\%C8\%9B\%C4\%83-noi-realit\%C4\%83\%C8\%9Bi-\%C3\%AEnreglementarea-conflictului-transnistrean.htm, accessed 5/10/2020.

Deschide.md (2020b): VIDEO//Mai mulți cetățeni din stânga Nistrului au blocat podul Râbniţa-Rezina cerând dreptul la libera circulație [VIDEO//Several citizens from the left bank of Nistru blocked the Rabnita-Rezina bridge]. https://deschide.md/ro/stiri/23/68715/video-mai-mul-i-cet-eni-din-stanganistrului-au-blocat-podul-rabni-a-rezina-cerand-dreptul-la-libera-circula-ie.htm, accessed 07/11/2020.

Dulgher, M. (2020): UNDP Moldova Report: Impact of COVID-19 on Economic Sectors. Moldova.org. https://www.moldova.org/en/undp-moldova-report-impact-of-covid-19-on-economic-sectors/, accessed 27/12/2020.

Emerson, M. - Akhvlediani, T. - Cenusa, D. - Ismayil, S. - Movchan, V. - Poghosyan, B. - Remizov, A. Waal, T. - Yahorau, A. (2020): Special Theme: COVID-19 in the Separatist Conflict Regions. Eastern Partnership - COVID-19 Bulletin 6.

EU4Moldova (2020): Centrul de sănătate Varnița care oferă servicii medicale persoanelor de pe ambele maluri ale Nistrului (Susținerea Măsurilor de Promovare a Încrederii) [Varnita Health Center offers medical services to people from both banks of Nistru (Supporting Confidence-Building Measures)]. https://www.eu4moldova.md/ro/content/centrul-de-s\%C4\%83n\%C4\%83tate-varni\%C8\%9Ba-care-ofer $\%$ C4\%83-servicii-medicale-persoanelor-de-pe-ambele-maluri-ale, accessed 30/11/2020.

Fomenco V. (2019): Migration of the Population of Transnistria: Factors, Trends, Consequences. Journal of Geography, Politics and Society 9(4): 1-11.

Gibson, C. - Arya, N. - Ponka, D. - Rouleau, K. - Woodlard, R. (2016): Approaching a Global Definition of Family Medicine. Canadian Family Physician 62: 891-896. 
Gorchak, O. (2020): В Приднестровье ввели новые ограничения из-за коронавируса [New restrictions were introduced in Transnistria due to the Coronavirus]. Newsmaker.md. https:// newsmaker.md/rus/novosti/v-pridnestrove-vveli-novye-ogranicheniya-iz-za-koronavirusa/, accessed 20/11/2020.

Grâu, L. (2020a): Tiraspolul instalează noi posturi de control şi reține persoane sub pretextul carantinei [Tiraspol Installs New Checkpoints and Arrests People with the Pretext of the Quarantine]. Radio Europa Liberă Moldova. https://moldova.europalibera.org/a/tiraspolul-instaleaz\%C4\%83-noi-postulde-control-\%C8\%99i-re\%C8\%9Bine-persoane-sub-pretextul-carantinei/30540137.html, accessed 10/ 05/2020.

Grâu, L. (2020b): Măşti de protecție, produse in regiunea transnistreană [Protective Masks, Produced in the Transnistrian Region]. Radio Europa Liberă Moldova. https://moldova.europalibera.org/a/30501340. html, accessed 30/11/2020.

Greadcenco, O. (2016): Servicii stomatologice pentru deținuții din Tiraspol, din bani suedezi [Dentistry services for detainees in Tiraspol with Swedish money]. Moldova.org. https://www.moldova.org/ servicii-stomatologice-pentru-detinutii-din-tiraspol-din-bani-suedezi/, accessed 30/11/2020.

Gulca, I. (2020): Moldova: Pandemic Brinkmanship Brings Strife to 'Security Zone'. Balkan Insight. https:// balkaninsight.com/2020/09/21/moldova-pandemic-brinkmanship-brings-strife-to-security-zone/, accessed 01/10/2020.

Gulca, I. - Necşuțu, M. (2019): The Cryptorepublic. Anticorupție.md. https://www.anticoruptie.md/en/ investigations/economic/the-cryptorepublic, accessed 13/05/2020.

Guvernul Republicii Moldova (2010): HOTĂR̂िRE Nr. 906 din 24-09-2010 privind crearea și activitatea comisiilor pentru examinarea adresărilor cetăţenilor Republicii Moldova domiciliați în localităţile din stînga Nistrului (Transnistria) şi localităţile limitrofe acestora din categoriile pentru care calitatea de asigurat o are Guvernul [DECISION number 906 from 24-09-2010 on the creation and activity of the commissions for examining requests of citizens of the Republic of Moldova living in localities from the left bank of Nistru (Transnistria) and the adjacent localities from the categories for which the status of insured is registered by the Government]. https://www.legis.md/cautare/getResults?doc_ $\mathrm{id}=103292$ \&lang $=$ ro, accessed 30/11/2020.

Guvernul Republicii Moldova (2020): Tiraspolul a refuzat repetat să participe la Grupul de lucru pentru ocrotirea sănătății [Tiraspol repeatedly refused to participate in the health protection working group]. https://gov.md/ro/content/tiraspolul-refuzat-repetat-sa-participe-la-grupul-de-lucru-pentru-ocrotireasanatatii, accessed 01/06/2020.

Homlok D. T. (2019): Health System. In: Romaniuk, S. - Thapa, M. - Marton, P. (eds): The Palgrave Encyclopedia of Global Security Studies. Cham: Palgrave Macmillan.

Homlok, D. T. (2020): Public Health in Failing States. In: Romaniuk, S. - Thapa, M. - Marton, P. (eds): The Palgrave Encyclopedia of Global Security Studies. Cham: Palgrave Macmillan.

King, C. (2011): The Benefits of Ethnic War: Understanding Eurasia's Unrecognized States. World Politics 53(4): 524-552.

ICG (2020): The COVID-19 Challenge in Post-Soviet Breakaway State. Crisis Group Europe Briefing 89.

Istoricheskii Fakultet MGU (2020): Конститучия Союза Советских Социалистических Республик

[The Constitution of the Union of the Soviet Socialist Republics]. http://www.hist.msu.ru/ER/Etext/ cnst1977.htm, accessed 26/12/2020.

Mas-Coma, S. - Malcolm K. J. - Aileen M. M. (2020): COVID-19 and Globalization. One Health 9: 100132.

Mihailovici, S. (2020): Chişinăul livrează loturi de medicamente la Tiraspol. Șase cazuri confirmate de coronavirus şi peste 1500 de persoane plasate in carantină în regiunea transnistreană [Chisinau delivers 
medicine to Tiraspol. Six confirmed cases of coronavirus and over 1500 people placed under quarantine in the Transnistrian region]. TV8. https://tv8.md/2020/03/25/chisinaul-livreaza-loturi-demedicamente-la-tiraspol-sase-cazuri-confirmate-de-coronavirus-si-peste-1500-de-persoane-plasate-incarantina-in-regiunea-transnistreana/, accessed 10/05/2020.

Minzdrav (2020a): План подготовки проектов законов на 2020 год. Министерство здравоохранения Приднестровской Молдавской Республики [Plan for preparing draft laws for 2020. Ministry of Healthcare of the Pridnestrovian Moldovan Republic]. http://minzdrav.gospmr.org/ dokumenti/plan-grafik-normativno-pravovoy-raboti-na-2020-god/plan-podgotovki-proektovzakonov-na-2020-god.html, accessed 30/11/2020.

Minzdrav (2020b): Коронавирус: официальная информация [Coronavirus: official information]. http:// minzdrav.gospmr.org/covid-19/, accessed 30/11/2020.

Minzdrav (2020c): Коронавирус (2019-nCoV) [Coronavirus (2019-nCoV)]. http://minzdrav.gospmr.org/ ohrana-zdorovjya/koronavirus-2019-ncov/, accessed 30/11/2020.

Minzdrav (2020d): Дайджест №2 [Digest number 2]. http://minzdrav.gospmr.org/o-ministerstve/nashidostijeniya/dayjest-2.html, accessed 08/11/2020.

Minzdrav (2020e): Оперитаб: Занято 83\% коечного фонда [Operational Headquarters: 83\% of the bed stock is occupied]. http://minzdrav.gospmr.org/press-tsentr/sobitiya-operativnogo-shtaba/opershtabzanyato-83-koechnogo-fonda.html, accessed 30/11/2020.

Morgoci, S. (2007): Evaluarea sistemului de sănătate din regiunea transnistreană [Evaluation of the health system in the Transnistrian region]. Chişinău, Institutul de Politici Publice.

MVD PMR (2020): Плюс 100 тысяч тестов на антиген к COVID-19 [100 thousand more antigen tests for COVID-19]. https://www.mvdpmr.org/novosti/glavnaya-tema-koronavirus/33397-plyus-100tysyach-testov-na-antigen-k-covid-19.html, accessed 30/11/2020.

National Coordination Council (2016): Republic of Moldova Progress Report on HIV/AIDS. Chisinau: National Coordination Council.

Novosti Pridnestrovya (2019): Семейные врачи и системный подход. Концепция развития здравоохранения расставила акценты [Family doctors and systemic approach. The concept of healthcare development set the accents]. https://novostipmr.com/ru/news/19-11-29/semeynye-vrachi-isistemnyy-podhod-koncepciya-razvitiya, accessed 27/12/2020.

Novosti Pridnestrovya (2020a): Проект Концепции развития здравоохранения ПМР представили президенту [Concept project on the development of the PMR healthcare was presented to the president]. https://novostipmr.com/ru/news/20-03-13/proekt-koncepcii-razvitiya-zdravoohraneniyapmr-predstavili, accessed 30/11/2020.

Novosti Pridnestrovya (2020b): Минздрав: 75\% заболеваний должны лечиться специалистами общеврачебной практики [Healthcare Ministry: 75\% of diseases should be treated by general practice specialists]. https://novostipmr.com/ru/news/20-02-27/minzdrav-75-zabolevaniy-dolzhno-lechitsyaspecialistami, accessed 30/11/2020.

Novosti Pridnestrovya (2020c): В Приднестровъе 179 новых инфицированных COVID-19 [In Transnistria there are 179 new infected with COVID-19], https://novostipmr.com/ru/news/20-11-30/vpridnestrove-179-novyh-inficirovannyh-covid-19, accessed 30/11/2020.

Novosti Pridnestrovya (2020d): Оперитаб при Президенте: За четьре дня выявлено 1119 случаев коронавируса [President's Operational Headquarters: In four days, 1119 new cases of the coronavirus cases were revealed]. https://novostipmr.com/ru/news/20-11-30/opershtab-pri-prezidente-za-chetyrednya-vyyavleno-1-119-sluchaev, accessed 30/11/2020. 
Novosti Pridnestrovya (2020e): Столичная COVID-лаборатория вышла из строя из-за сильной нагрузки [COVID laboratory from the capital broke down because of heavy load]. https://novostipmr. com/ru/news/20-11-26/iz-za-kolossalnoy-nagruzki-iz-stroya-vyshla-laboratoriya-na-baze, accessed 26/ $11 / 2020$.

Novosti Pridnestrovya (2020f): Заявление МИД ПМР в связи политизацией Молдовой вопросов здравоохранения [Statement of MID PMR regarding the politicization by Moldova of the questions of healthcare]. https://novostipmr.com/ru/news/20-06-09/zayavlenie-mid-pmr-v-svyazi-politizacieymoldovoy-voprosov, accessed 11/06/2020.

Novosti Pridnestrovya (2020g): Первые случаи заражения коронавирусом зафиксированы в Совместных миротворческих силах [First cases of coronavirus infections were registered in the Joint peacekeeping forces]. https://novostipmr.com/ru/news/20-07-02/pervye-sluchai-zarazheniyakoronavirusom-zafiksirovany-v, accessed 09/11/2020.

Novosti Pridnestrovya (2020h): Оперитаб при Президенте: В Приднестровье прибыло 10 тонн груза медицинского назначения [President's Operational Headquarters: 10 tons of medical load arrived in Transnistria]. https://novostipmr.com/ru/news/20-05-12/opershtab-pri-prezidente-vpridnestrove-pribylo-10-tonn-gruza, accessed 09/06/2020.

PGU (2020): Медицинский факультет [Medical faculty]. Available at: http://spsu.ru/university/struct/ mf, accessed 20/11/2020.

Protsyk, P. (2006): Moldova's Dilemmas in Democratizing and Reintegrating Transnistria. Problems of Post-Communism 53(4): 29-41.

Saunders-Hastings, P. R. - Krewski, D. (2016): Reviewing the History of Pandemic Influenza: Understanding Patterns of Emergence and Transmission. Pathogens 5(4): 66.

Sheriff (2020): 10 миллионов рублей для тех, кто борется с коронавирусом [10 million roubles for those who fight the coronavirus]. https://sheriff.md/pressroom/news/?id=147, accessed 08/05/2020.

Shrestha, N. - Shad, M. Y. - Ulvi, O. - Khan, M. H. - Karamehic-Muratovic, A. - Nguyen, U., Baghbanzadeh, M. - Wardrup, R. - Aghamohammadi, N. - Cervantes, D. - Nahiduzzaman, K. M. - Zaki, R. A. - Haque, U. (2020): The impact of COVID-19 on globalization. One Health 11: 100180.

Sputnik Moldova (2019): Эксперт ВОЗ: системе здравоохранения Приднестровья нужна реструктуризация [WHO experts: Transnistria's healthcare system needs restructuring]. https://ru. sputnik.md/society/20190711/26812394/ekspert-voz-sisteme-zdravookhraneniya-pridnestrovyanuzhna-restrukturizatsiya.html, accessed 27/12/2020.

Tkhorik, V. - Tuzlova, M. - Zvarish, N. (2017): Контрабандная «гуманитарка» для Приднестровья [Counterband "Humanitarian" (Assistance) for Transnistria]. Rise Moldova, 29 June 2017. https:// www.rise.md/rusa/\%D0\%BA\%D0\%BE\%D0\%BD\%D1\%82\%D1\%80\%D0\%B0\%D0\%B1\%D0\%B0\%D0\% BD\%D0\%B4\%D0\%BD\%D0\%B0\%D1\%8F-\%D0\%B3\%D1\%83\%D0\%BC\%D0\%B0\%D0\%BD\%D0\%B8\% D1\%82\%D0\%B0\%D1\%80\%D0\%BA\%D0\%B0-\%D0\%B4\%D0\%BB\%D1\%8F-\%D0\%BF\%D1\%80\%D0\% B8/, accessed 30/11/2020.

Turcanu, G. - Domente, S. - Buga, M. - Richardson, E. (2012): Republic of Moldova: Health System Review. Health Systems in Transition 14(7): 1-151.

TVR Moldova (2020): Reprezentantul OMS în Republica Moldova a identificat o serie de nereguli în gestionarea crizei pandemice din regiunea transnistreană [WHO representative in the Republic of Moldova identified a series of irregularities in the management of the pandemic crisis in the Transnistrian region]. http://tvrmoldova.md/actualitate/reprezentantul-oms-in-republica-moldova-a-identificat-oserie-de-nereguli-in-gestionarea-crizei-pandemice-din-regiunea-transnistreana/, accessed 09/06/2020. 
UL PMR (2014): Постановление Правительства Приднестровской Молдавской Республики об утверждении Концепции развития здравоохранения Приднестровской Молдавской Республики на 2015 год и среднесрочную перспективу [Order of the Government of the Pridnestrovian Moldovan Republic about the approval of the Concept of the development of the healthcare of the Pridnestrovian Moldovan Republic for 2015 and the medium-term perspective]. https://ulpmr. $\mathrm{ru} / \mathrm{ul} / \mathrm{show} / \mathrm{aVswVHDFeEJ4c8qOfzyQ1M51zn9PbWsNvZxc=}$, accessed 30/11/2020.

US Department of State (2018): 2018 Country Reports on Human Rights Practices: Moldova. Washington DC: Bureau of Democracy, Human Rights and Labor.

US Department of State (2014): 2014 Country Reports on Human Rights Practices: Moldova. Washington DC: Bureau of Democracy, Human Rights and Labor.

Vlas C. (2020a): Public Health in Breakaway Regions. In: Romaniuk, S. - Thapa, M. - Marton P. (eds): The Palgrave Encyclopedia of Global Security Studies. Cham: Palgrave Macmillan.

Vlas, C. (2020b): Peacekeeping Mission on the Nistru River: Effectiveness and Viability. MA/MSc thesis. Corvinus Univesity of Budapest. http://publikaciok.lib.uni-corvinus.hu/publikus/szd/Vlas_Cristian.pdf, accessed 30/11/2020.

Waal, T. (2019): Transdniestria Today. 3DCFTAs. https://3dcftas.eu/publications/transdniestria-today, accessed 30/11/2020.

WHO (2020): Coronavirus. https://www.who.int/health-topics/coronavirus\#tab=tab_1, accessed 20/11/ 2020.

WHO (2008): The Tallinn Charter: Health Systems for Health and Wealth. Tallinn: WHO Regional Office for Europe.

World Bank (1998): Republic of Moldova Economic Review of the Transnistria Region. http://documents1. worldbank.org/curated/en/492631468773991051/pdf/multi0page.pdf, accessed 27/12/2020.

Open Access. This is an open-access article distributed under the terms of the Creative Commons Attribution-NonCommercial 4.0 International License (https://creativecommons.org/licenses/by-nc/4.0/), which permits unrestricted use, distribution, and reproduction in any medium for non-commercial purposes, provided the original author and source are credited, a link to the CC License is provided, and changes - if any - are indicated. 